Article

\title{
Comparing the Effects of Types of Electrode on the Removal of Multiple Pharmaceuticals from Water by Electrochemical Methods
}

\author{
Yu-Jung Liu ${ }^{1} \mathbb{D}$, Yung-Ling Huang ${ }^{2}$, Shang-Lien Lo ${ }^{1}$ and Ching-Yao $\mathrm{Hu}^{2, * \mathbb{D}}$ \\ 1 Graduate Institute of Environmental Engineering, National Taiwan University, Taipei 106, Taiwan; \\ yujungliu77@gmail.com (Y.-J.L.); sllo@ntu.edu.tw (S.-L.L.) \\ 2 School of Public Health, Taipei Medical University, Taipei 110, Taiwan; m508101008@tmu.edu.tw \\ * Correspondence: cyhu@tmu.edu.tw
}

Received: 20 July 2020; Accepted: 18 August 2020; Published: 19 August 2020

\begin{abstract}
Considering the lack of information on simultaneously removing multiple pharmaceuticals from water or wastewater by electrochemical methods, this study aimed to investigate the removal of multiple pharmaceuticals by electro-coagulation and electro-oxidation based on two types of electrodes (aluminum and graphite). The synthetic wastewater contained a nonsteroidal anti-inflammatory drug (diclofenac), a sulfonamide antibiotic (sulfamethoxazole) and a $\beta$-blocker (atenolol). The pharmaceutical removal with electro-oxidation was much higher than those with the electro-coagulation process, which was obtained from a five-cell graphite electrode system, while the removal of pharmaceuticals with aluminum electrodes was about $20 \%(20 \mu \mathrm{M})$. In the electro-coagulation system, pharmaceutical removal was mainly influenced by the solubility or hydrophilicity of the compound. In the electro-oxidation system, the removal mechanism was influenced by the dissociation status of the compounds, which are attracted to the anode due to electrostatic forces and have a higher mass transformation rate with the electro-oxidation process. Therefore, atenolol, which was undissociated, cannot adequately be eliminated by electro-oxidation, unless the electrode's surface is large enough to increase the mass diffusion rate.
\end{abstract}

Keywords: $\beta$-blockers; electro-coagulation; electro-oxidation; nonsteroidal anti-inflammatory drugs (NSAIDs); sulfonamide antibiotics

\section{Introduction}

The presence of emerging pharmaceutical contaminants has drawn much attention in recent years; however, these substances are inefficiently removed by conventional unit operations utilized by most wastewater treatment plants (WWTPs) due to their intricate properties like high water solubility and poor biodegradability [1-6]. Among such pharmaceuticals, nonsteroidal anti-inflammatory drugs (NSAIDs), beta-blockers, and antibiotics are widely used groups, and thus these groups are most often found in wastewater, which may co-exist in water bodies and soil environment $[1,6,7]$. They may induce adverse effects on aquatic systems [6,8-11].

An electrochemical process was applied to broad applicability like textile, cellulose, paper factories, laundry, and various kinds of different characteristic wastewater [12-18]. This technology can be operated by separation and degradation, called electro-coagulation and electrochemical oxidation, which depends on the characteristics of the electrodes [18-20]. In a separation system, electro-coagulation involves applying electric current to sacrificial electrodes where coagulants and gas bubbles are generated in situ by the current, and destabilizes, suspends, emulsifies or dissolves pollutants in an aqueous medium, or floats pollutants to the surface by tiny bubbles of hydrogen and oxygen gases generated from water electrolysis [21]. Additionally, the stable complexation between pollutants and flocs might be due to the 
structure of the pollutants, which might be the assumption for high selectivity by the metal adsorption capacity of the ligand-based-like flocs [22-24]. In a degradation system, electro-oxidation occurs through two routes, (1) direct oxidation, where the pollutants eliminated at the anode surface; (2) indirect oxidation, where mediators (reactive oxygen species or active chlorine species) are anodically generated to carry out the reaction $[20,25]$. The electrochemical methods have the advantages of simple equipment, flexible operation, and being chemical free [26,27]. Although it requires wastewater under high conductivity and energy consumption, it still has high treatment efficiency with chloride without any secondary pollutants, and the reusability of chloride with relatively low costs, which is the concept of green chemistry [21,26-30].

Previous studies have focused on single pharmaceutical removal efficiencies by using electro-coagulation and electro-oxidation processes $[19,20,31]$. However, many pharmaceuticals are simultaneously present in the environment. To the best of our knowledge from reviewing the literature, less reports are available to date on removing multiple pharmaceuticals from water or wastewater using an electrochemical process. Accordingly, this study aimed to evaluate the effect of laboratory-scale electrochemical treatments of wastewater on removing multiple pharmaceuticals from synthetic water and spiked wastewater. We evaluated the effectiveness of aluminum and graphite electrodes in monopolar and bipolar arrangements under consideration for electrochemical utilization methods to eliminate a beta-blocker (atenolol; ATE), an NSAID (diclofenac; DIC), and a sulfonamide antibiotic (sulfamethoxazole; SMX).

\section{Materials and Methods}

\subsection{Materials}

Characteristics of the target compounds are shown in Table 1. All the chemicals were an analytical grade $(\geq 98 \%)$. DIC $\left(\mathrm{C}_{14} \mathrm{H}_{11} \mathrm{Cl}_{2} \mathrm{NO}_{2}\right)$ and $\mathrm{SMX}\left(\mathrm{C}_{10} \mathrm{H}_{11} \mathrm{~N}_{3} \mathrm{O}_{3} \mathrm{~S}\right)$ were purchased from Sigma-Aldrich; ATE $\left(\mathrm{C}_{14} \mathrm{H}_{22} \mathrm{~N}_{2} \mathrm{O}_{3}\right)$ was from TCI; and sodium chloride $(\mathrm{NaCl})(99.5 \%$; Wako) was used as the supporting electrolyte to prevent passive film generated during the reaction, which may increase the resistance and diminish the release of the coagulants from the electrode [21,32,33]. Monopotassium phosphate $\left(\mathrm{KH}_{2} \mathrm{PO}_{4}\right.$ ) (99\%; Showa), methanol (high-performance liquid chromatography (HPLC) grade; Scharlau), and acetonitrile (HPLC grade; J.T. Baker) were used in the HPLC analyses. Stock solutions were prepared with deionized Milli-Q water obtained from a Merck-Millipore system and were stored in amber glass bottles at $4{ }^{\circ} \mathrm{C}$. The standard solutions of target compounds at various concentrations were prepared by diluting the stock solutions prior to use. The anodes and cathodes used were $99 \%$ pure aluminum as the sacrificial electrodes, and graphite as the non-sacrificial electrodes.

Table 1. Characteristics of the target compounds.

\begin{tabular}{|c|c|c|c|c|c|c|}
\hline Categories & $\begin{array}{l}\text { Compound } \\
\text { (CAS Number) }\end{array}$ & Structure & $\begin{array}{c}\mathrm{MW} \\
\left(\mathrm{g} \mathrm{mol}^{-1}\right)\end{array}$ & $\begin{array}{l}\text { Solubility } \\
\text { (mg/L) }\end{array}$ & $\mathrm{pK}_{\mathrm{a}}$ & $\log K_{\text {ow }}$ \\
\hline$\beta$-blocker & $\begin{array}{l}\text { Atenolol (ATE) } \\
(29122-68-7)\end{array}$ & & 266.34 & 300 & 9.6 & 0.16 \\
\hline $\begin{array}{l}\text { Nonsteroidal } \\
\text { anti-inflammatory } \\
\text { drug (NSAID) }\end{array}$ & $\begin{array}{c}\text { Diclofenac (DIC) } \\
(15307-86-5)\end{array}$ & & 296.13 & 2.37 & 4.15 & 4.51 \\
\hline $\begin{array}{l}\text { Sulfonamide } \\
\text { antibiotic }\end{array}$ & $\begin{array}{c}\text { Sulfamethoxazole } \\
\text { (SMX) (723-46-6) }\end{array}$ & & 253.28 & 370 & 5.7 & 0.89 \\
\hline
\end{tabular}

\subsection{Electrochemical (EC) Experiments and Analyses}

EC experiments were carried out in a $1 \mathrm{~L}$ reactor, which is a double layered cylindrical glass container, with a diameter of $10 \mathrm{~cm}$ and a height of $20 \mathrm{~cm}$, as schematically shown in Figure 1 . The cell was operated with 2 and 6 electrodes held vertically, respectively; each electrode was $1 \mathrm{~mm}$ thick and 
had an effective area of $125 \mathrm{~cm}^{2}$; the distance between the electrodes was 100 and $24 \mathrm{~mm}$, respectively. All electrochemical experiments were carried out under potent stirring with a magnetic bar at 260 rpm and a constant current intensity ( $\mathrm{I}=0.5 \mathrm{~A}$ ) provided by direct current (DC) (GPR-30H10D, Good Will Instrument). Desired concentrations of the pharmaceutical stock solutions (10 mM) were made by adding proper amounts of pharmaceuticals to distilled water. The volume $(\mathrm{V})$ of the solution of each batch was $1 \mathrm{~L}$ with $100 \mu \mathrm{M}$ of each pharmaceutical (ATE, DIC, and SMX) and $0.01 \mathrm{M} \mathrm{NaCl}$ as the supporting electrolyte. Solutions were maintained at $25 \pm 1{ }^{\circ} \mathrm{C}$ in a water-bath. Samples were taken at assigned time intervals following the achievement of the EC process. The total reaction time was set to 20 or $40 \mathrm{~min}$, which depended on what was required for the electrode cells to achieve a suitable removal efficiency. Pharmaceutical concentrations were investigated by high-performance liquid chromatography (HPLC; Hitachi, L-7200, Japan) with a diode array detector (DAD; Hitachi, L-7455, Japan), equipped with a $\mathrm{C}_{18}$ column (RP-18 GP $150 \times 4.6 \mathrm{~mm}, 5 \mu \mathrm{m}$, Mightysil). HPLC-DAD is a relatively cheap and simple operation technique for screening and analyzing purposes on gradient elution [34]. Mobile phase $\mathrm{A}$ was $\mathrm{KH}_{2} \mathrm{PO}_{4}, \mathrm{~B}$ was acetonitrile, and the specific conditions are shown in Table 2. The flow rate of mobile phases $\mathrm{A}$ and $\mathrm{B}$ were both set to $1 \mathrm{~mL} \mathrm{~min}{ }^{-1}$. The injected volume of each sample was $20 \mu \mathrm{l}$. The deviations of all analyses were within $5 \%$. Quality assurance/quality control $(\mathrm{QA} / \mathrm{QC})$ standards were prepared by diluting and combining the $0.01 \mathrm{M}$ pharmaceutical stock solution accordingly, and to monitor HPLC-DAD performances.

Table 2. Conditions of HPLC-diode array detector (DAD).



(a) 1-cell

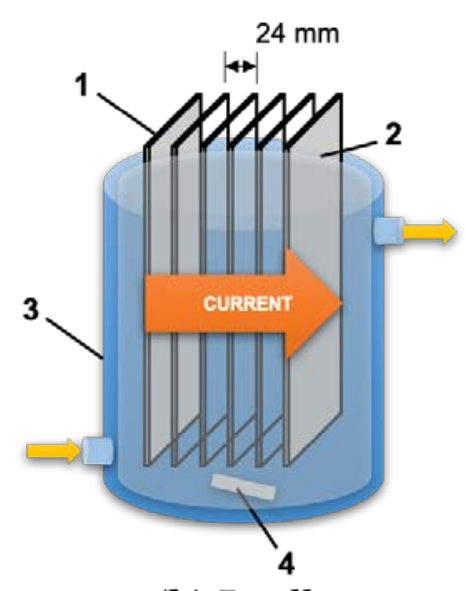

(b) 5-cell

Figure 1. Profile of the batch reactor: (a) 1 cell and (b) 5 cell. 1: anode (aluminum, graphite). 2: cathode (aluminum, graphite). 3: Double layered cylindrical glass container $(\forall=1 \mathrm{~L})$ with a water bath. 4 : magnetic stirring bar. 


\section{Results and Discussion}

\subsection{Removal of ATE, DIC, and SMX with Different Electrode Systems}

Three electrode arrangements were investigated for single pharmaceutical removal in the batch electrochemical method with sacrificial and non-sacrificial anodes, under conditions of the present study, and two mechanisms were responsible for the removal of the pollutants: electro-coagulation, and electro-oxidation. We choose aluminum electrodes used as model sacrificial anode; graphite electrodes used as non-sacrificial anode. Figure 2a shows that removal rates of DIC, SMX, and ATE by the aluminum electrode system were $17.9 \%, 4.8 \%$, and $2.3 \%$, respectively. These results are similar to those of our previous study [19]; the substance with lipophilic characteristic could be removed either by precipitation of the flocs or by flotation with hydrogen gas during the electro-coagulation reaction, which depended on adsorption $[35,36]$ and charge neutralization on the surface of hydrogen bubbles and aluminum hydroxide [37]. Additionally, it might be due to the soft atoms that are favorable for stable complexation mechanism, and this might be the main assumption for the high selectivity by the $\mathrm{Al}$ (II) adsorption capacity of the ligand-based flocs [22].

The main mechanism of pharmaceutical removal in the graphite electrode system should be electrochemical oxidation, which involves two procedures when an electric current is passed through a non-sacrificial electrode. The first one is the direct electrolysis of the pharmaceuticals on the surface of the anodes. The other one is indirect oxidation which involves a strong oxidant $(\bullet \mathrm{OH}$ or $\mathrm{HOCl})$ produced by the electrolysis of chloride or other compounds [20]. The oxidant is then transferred to the bulk solution to degrade the pharmaceuticals, and this process may cause the structure of the initial pollutant to be converted into byproducts [18,20]. DIC, SMX, and ATE, as shown in Figure 2b, were reduced by $100 \%, 99.8 \%$, and $85 \%$, respectively. The higher removal of DIC and SMX may have been due to the dissociation of the two compounds in the reaction conditions. As shown in Table 1, pKa values of both DIC and SMX are relatively smaller than that of ATE, which means the two compounds are dissociated in a neutral condition but ATE is not. The mass transfer rate of anions should be much higher than that of neutral compounds because of electrostatic forces. The removal efficiencies of ionic compounds such as DIC and SMX by electro-oxidation were higher than that of the neutral compound of ATE. The schemes of the mechanism of electro-coagulation and electro-oxidation are shown in Figure 3.

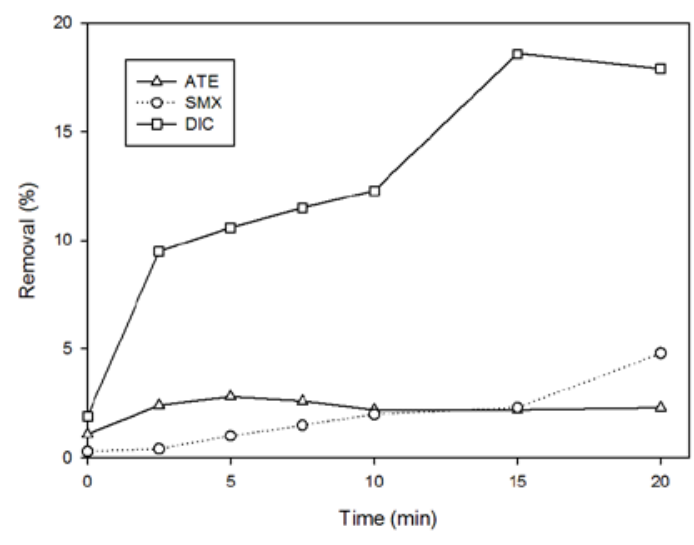

(a)

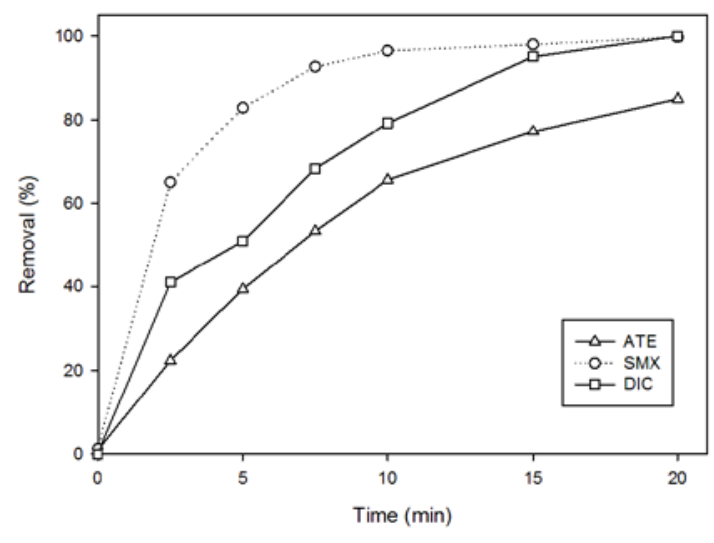

(b)

Figure 2. Removal efficiencies of single pharmaceuticals in a $1 \mathrm{~L}$ batch reactor with a 5-cell system of (a) aluminum or (b) graphite ([Phar. $\left.]_{0}=100 \mu \mathrm{M},[\mathrm{NaCl}]=0.01 \mathrm{M}, \mathrm{I}=0.5 \mathrm{~A}\right)$. 

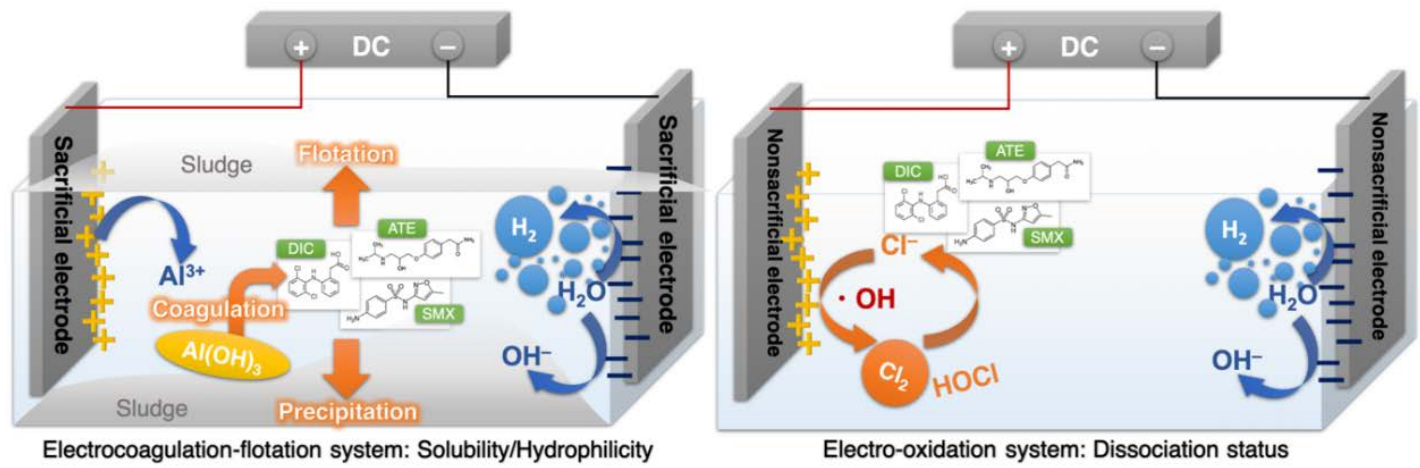

Figure 3. Schemes of the mechanism of electro-coagulation and electro-oxidation.

\subsection{Removal Efficiencies of Multiple Pharmaceuticals}

The above observations reveal that the removal efficiencies of single pharmaceuticals changed with different electrodes, especially in the graphite electrode system. To utilize this system in a practical way, as shown in Figure 4, the influences of the electrode cell size in the triple-pharmaceutical solutions should be considered. The removal of multiple pharmaceuticals in a 1-cell system was inefficient, especially for ATE. Compared to the one-cell electrode, five-cell electrodes were significantly more effective at removing multiple pharmaceuticals from the water, with removal rates of SMX, DIC, and ATE of $75 \%, 68 \%$, and $55 \%$, respectively. The reason could also be due to the dissociation of the selected pharmaceuticals. On the other hand, the synergistic effects of direct and mediated oxidation may be another possibility causing this circumstance. Hydroxyl radicals $(\bullet \mathrm{OH})$ produced by the oxidation of water are known to be a very active reagent and lead to the formation of higher-state oxides or superoxides (Equations (1) and (2)). Using sodium chloride $(\mathrm{NaCl})$ as the electrolyte provided the formation of hypochlorous acid ( $\mathrm{HOCl}$ ) (Equation (3)). Accordingly, the oxidation of pharmaceuticals occurred more effectively since $\bullet \mathrm{OH}$ and $\mathrm{HOCl}$ were generated in the five-cell electrode system:

$$
\begin{gathered}
\mathrm{M}+\mathrm{H}_{2} \mathrm{O} \rightarrow \mathrm{M}(\bullet \mathrm{OH})+\mathrm{H}^{+}+\mathrm{e}^{-} \\
\mathrm{M}(\bullet \mathrm{OH}) \rightarrow \mathrm{MO}+\mathrm{H}^{+}+\mathrm{e}^{-} \\
\mathrm{Cl}^{-}+\mathrm{H}_{2} \mathrm{O} \rightarrow \mathrm{HOCl}+\mathrm{H}^{+}+2 \mathrm{e}^{-}
\end{gathered}
$$

To clarify the interactions between multiple pharmaceuticals in the electro-oxidation reaction, variations in removal rates of double pharmaceuticals with the reaction times in the graphite electrode system are shown in Figure 4. When ATE and SMX existed simultaneously (Figure 5a), only SMX could effectively be removed, at 69.9\%. The same tendency is shown in Figure 5b of DIC and ATE concurrently. Elimination rates of DIC and ATE were $94.8 \%$ and $63.4 \%$. Figure $5 \mathrm{c}$ shows that elimination rates of SMX and DIC were $75.2 \%$ and $73.7 \%$.

As a result of the behavior described above, the structure and characteristics of the pharmaceuticals were the most important factors. Difficulty with cleavage affected the removal of multiple pharmaceuticals, which is related to competitive oxidation [38]. The S-N bond, isoxazole ring, and benzene ring of SMX and DIC were easily cleaved during oxidation [39]. Moreover, it was found that DIC and SMX were more effectively removed than ATE. After the reaction, the $\mathrm{pH}$ of the solution was about $7 \pm 0.8$, but the pKa of ATE was 9.6. This observation indicated that ATE was still in a molecular state and had not reached the anode; DIC and SMX were dissociated into ionic compounds and were attracted to the anode, and thus were rapidly degraded through the electrochemical oxidation system. 


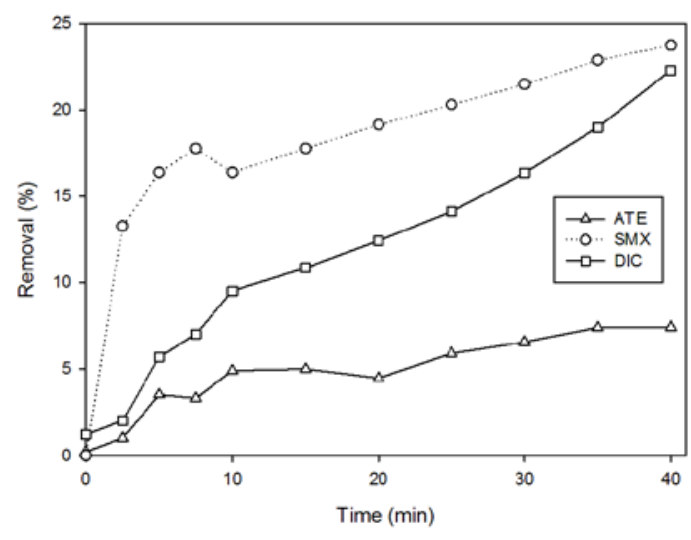

(a)

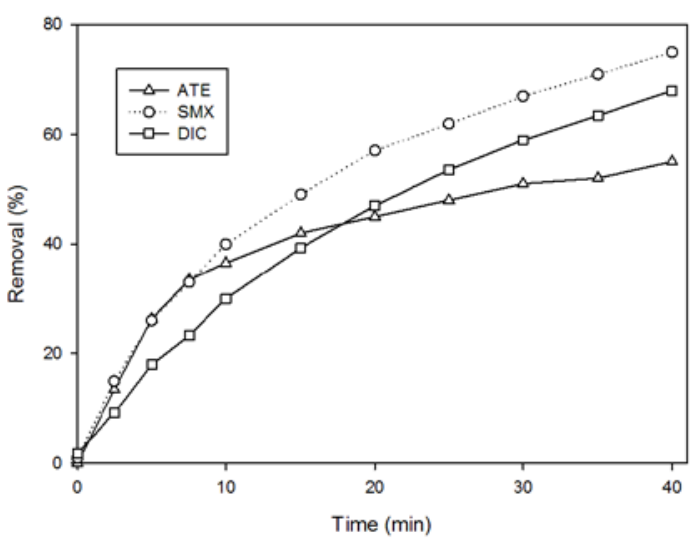

(b)

Figure 4. Removal efficiencies of triple pharmaceuticals in a $1 \mathrm{~L}$ batch reactor with a graphite electrode and a (a) 1 -cell or (b) 5-cell system ([Phar. $\left.]_{0}=100 \mu \mathrm{M},[\mathrm{NaCl}]=0.01 \mathrm{M}, \mathrm{I}=0.5 \mathrm{~A}\right)$.



(a)



(b)

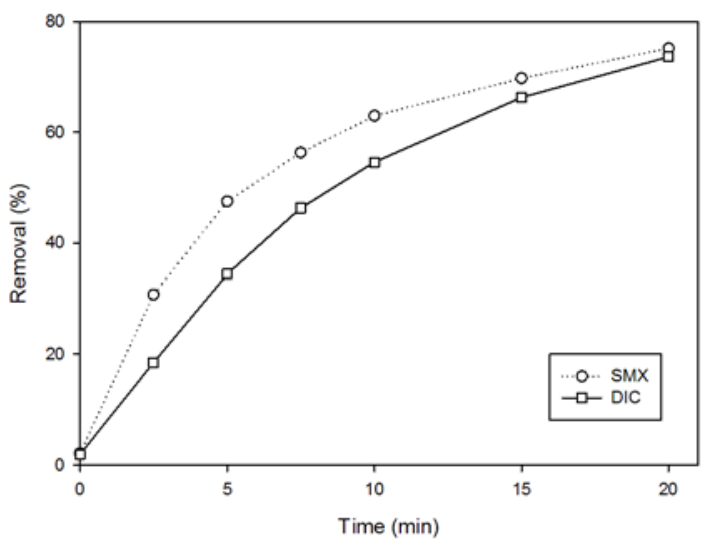

(c)

Figure 5. Removal efficiencies of dual pharmaceuticals in a $1 \mathrm{~L}$ batch reactor with 5-cell graphite electrodes $\left([\text { Phar. }]_{0}=100 \mu \mathrm{M},[\mathrm{NaCl}]=0.01 \mathrm{M}, \mathrm{I}=0.5 \mathrm{~A}\right)$. (a) ATE + SMX; (b) DIC + ATE; (c) SMX + DIC.

\subsection{Influences of Multiple Pharmaceuticals on Hospital Wastewater Matrixes}

To simulate pharmaceutical interactions in real wastewater matrixes, we spiked our target compounds into an actual hospital effluent. Table 3 shows the characteristics of the hospital effluent. Figure 6 shows 
the performances of multiple pharmaceuticals in the electro-oxidation system with graphite electrodes. Martins et al. indicated that if a solution has large amounts of organic compounds or complex matrixes, pharmaceuticals may be adsorbed or attached onto other species or structures, which decreases the removal efficiency [40]. These results reflect the same circumstances of our experiment outcomes. Compared to laboratory outcomes, the declines in ATE, DIC, and SMX in an actual hospital effluent were only $11 \%$, $47.8 \%$, and $43 \%$, respectively.

Table 3. Characteristics of hospital effluent.

\begin{tabular}{cc}
\hline Parameters & Hospital Effluent \\
\hline Temperature $\left({ }^{\circ} \mathrm{C}\right)$ & 25.0 \\
pH & 3.35 \\
Dissolved oxygen $(\mathrm{DO})(\mathrm{ppm})$ & 7.20 \\
Turbidity (NTU) & 10.9 \\
Suspended solids (SS) (mg/L) & 0.018 \\
Chemical oxygen demand (COD) $(\mathrm{mg} / \mathrm{L})$ & 41.5 \\
Biochemical oxygen demand (BOD) $(\mathrm{mg} / \mathrm{L})$ & 4.21 \\
\hline
\end{tabular}

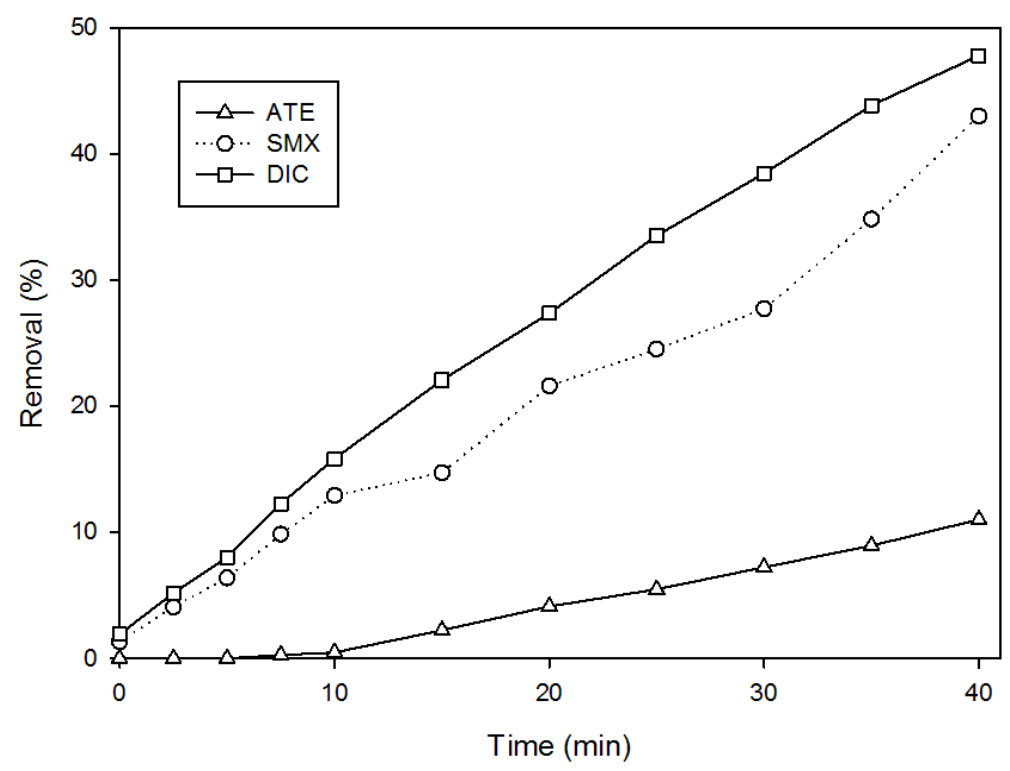

Figure 6. Removal efficiencies of spiked pharmaceuticals in actual hospital effluent matrices $\left([\text { Phar. }]_{\mathrm{S}}=\right.$ $100 \mu \mathrm{M},[\mathrm{NaCl}]=0.01 \mathrm{M}, \mathrm{I}=0.5 \mathrm{~A})$.

\section{Conclusions}

To develop promising treatments for removing pharmaceuticals from sewage, the ability of a physicochemical process, electrochemical treatment, to remove selected pharmaceuticals was assessed. Aluminum was used for the active electrodes with the electrocoagulation-flotation process; graphite was used for the inert electrodes with electro-oxidation. The electrochemical process with the graphite electrode system removed the pharmaceuticals in water more effectively with multiple electrodes by the electro-oxidation process. Removal efficiencies were affected by the hydrophobic character of the pharmaceuticals under the electrocoagulation-flotation system, and the uneven electron structural characteristics of the pharmaceuticals under the electro-oxidation system. According to these results, the degradation of pharmaceuticals was improved and more efficient than the separation of medicines.

Author Contributions: Y.-L.H. carried out the experiments. Y.-J.L. processed the experiments, analyzed the data, and wrote the manuscript in consultation with S.-L.L. and C.-Y.H. S.-L.L. devised the conceptual ideas, discussed the results, and commented on the manuscript. C.-Y.H. conceived the original idea, helped supervise the project, and final approval of the version to be published. All authors have read and agreed to the published version of the manuscript. 
Funding: This research received the funding from Ministry of Science and Technology, Taiwan, ROC (under contract no. MOST 107-2221-E-038-001).

Conflicts of Interest: The authors declare no conflict of interest.

\section{Abbreviations}

$\begin{array}{ll}\text { ATE } & \text { Atenolol } \\ \text { DAD } & \text { Diode Array Detector } \\ \text { DC } & \text { Direct Current } \\ \text { DIC } & \text { Diclofenac } \\ \text { EC } & \text { Electrochemical } \\ \mathrm{HOCl} & \text { Hypochlorous Acid } \\ \mathrm{HPLC} & \text { High-Performance Liquid Chromatography } \\ \mathrm{I} & \text { Current } \\ \mathrm{KH}_{2} \mathrm{PO}_{4} & \text { Monopotassium Phosphate } \\ \mathrm{NaCl}_{\mathrm{NS}} & \text { Sodium Chloride } \\ \mathrm{NSAIDs} & \text { Nonsteroidal Anti-Inflammatory Drugs } \\ \bullet \mathrm{OH} & \text { Hydroxyl Radicals } \\ {[\mathrm{Phar}]_{0}} & \text { Initial Concentration of Pharmaceutical } \\ {[\mathrm{Phar}]_{\mathrm{S}}} & \text { Initial Concentration of Spiked Pharmaceuticals } \\ \mathrm{QA} / \mathrm{QC} & \text { Quality Assurance/Quality Control } \\ \mathrm{SMX} & \text { Sulfamethoxazole }\end{array}$

\section{References}

1. Rivera-Utrilla, J.; Sánchez-Polo, M.; Ferro-García, M.Á.; Prados-Joya, G.; Ocampo-Pérez, R. Pharmaceuticals as emerging contaminants and their removal from water. A review. Chemosphere 2013, 93, 1268-1287. [CrossRef] [PubMed]

2. Crouse, B.A.; Ghoshdastidar, A.J.; Tong, A.Z. The presence of acidic and neutral drugs in treated sewage effluents and receiving waters in the Cornwallis and Annapolis River watersheds and the Mill CoveSewage Treatment Plant in Nova Scotia, Canada. Environ. Res. 2012, 112, 92-99. [CrossRef] [PubMed]

3. Li, Y.; Zhang, S.; Zhang, W.; Xiong, W.; Ye, Q.; Hou, X.; Wang, C.; Wang, P. Life cycle assessment of advanced wastewater treatment processes: Involving 126 pharmaceuticals and personal care products in life cycle inventory. J. Environ. Manag. 2019, 238, 442-450. [CrossRef] [PubMed]

4. Mestre, A.S.; Pires, R.A.; Aroso, I.; Fernandes, E.M.; Pinto, M.L.; Reis, R.L.; Andrade, M.A.; Pires, J.; Silva, S.P.; Carvalho, A.P. Activated carbons prepared from industrial pre-treated cork: Sustainable adsorbents for pharmaceutical compounds removal. Chem. Eng. J. 2014, 253, 408-417. [CrossRef]

5. Phoon, B.L.; Ong, C.C.; Mohamed Saheed, M.S.; Show, P.-L.; Chang, J.-S.; Ling, T.C.; Lam, S.S.; Juan, J.C. Conventional and emerging technologies for removal of antibiotics from wastewater. J. Hazard. Mater. 2020, 400, 122961. [CrossRef]

6. Khan, A.H.; Khan, N.A.; Ahmed, S.; Dhingra, A.; Singh, C.P.; Khan, S.U.; Mohammadi, A.A.; Changani, F.; Yousefi, M.; Alam, S.; et al. Application of advanced oxidation processes followed by different treatment technologies for hospital wastewater treatment. J. Clean. Prod. 2020, 269, 122411. [CrossRef]

7. Petrovic, M.; Hernando, M.D.; Diaz-Cruz, M.S.; Barcelo, D. Liquid chromatography-tandem mass spectrometry for the analysis of pharmaceutical residues in environmental samples: A review. J. Chromatogr. A 2005, 1067, 1-14. [CrossRef]

8. Verlicchi, P.; Al Aukidy, M.; Zambello, E. Occurrence of pharmaceutical compounds in urban wastewater: Removal, mass load and environmental risk after a secondary treatment-A review. Sci. Total Environ. 2012, 429, 123-155. [CrossRef]

9. Berninger, J.P.; Brooks, B.W. Leveraging mammalian pharmaceutical toxicology and pharmacology data to predict chronic fish responses to pharmaceuticals. Toxicol. Lett. 2010, 193, 69-78. [CrossRef]

10. Camacho-Muñoz, D.; Martín, J.; Santos, J.L.; Aparicio, I.; Alonso, E. Occurrence, temporal evolution and risk assessment of pharmaceutically active compounds in Donana Park (Spain). J. Hazard. Mater. 2010, 183, 602-608. [CrossRef] 
11. Xu, M.; Huang, H.; Li, N.; Li, F.; Wang, D.; Luo, Q. Occurrence and ecological risk of pharmaceuticals and personal care products (PPCPs) and pesticides in typical surface watersheds, China. Ecotox. Environ. Safe 2019, 175, 289-298. [CrossRef] [PubMed]

12. Essadki, A.H.; Bennajah, M.; Gourich, B.; Vial, C.; Azzi, M.; Delmas, H. Electrocoagulation/electroflotation in an external-loop airlift reactor-Application to the decolorization of textile dye wastewater: A case study. Chem. Eng. Process. Process Intensif. 2008, 47, 1211-1223. [CrossRef]

13. Boroski, M.; Rodrigues, A.C.; Garcia, J.C.; Gerola, A.P.; Nozaki, J.; Hioka, N. The effect of operational parameters on electrocoagulation-flotation process followed by photocatalysis applied to the decontamination of water effluents from cellulose and paper factories. J. Hazard. Mater. 2008, 160, 135-141. [CrossRef] [PubMed]

14. Chou, W.-L.; Wang, C.-T.; Chang, S.-Y. Study of COD and turbidity removal from real oxide-CMP wastewater by iron electrocoagulation and the evaluation of specific energy consumption. J. Hazard. Mater. 2009, 168, 1200-1207. [CrossRef]

15. Ge, J.; Qu, J.; Lei, P.; Liu, H. New bipolar electrocoagulation-electroflotation process for the treatment of laundry wastewater. Sep. Purif. Technol. 2004, 36, 33-39. [CrossRef]

16. Emamjomeh, M.M.; Sivakumar, M. Fluoride removal by a continuous flow electrocoagulation reactor. J. Environ. Manag. 2009, 90, 1204-1212. [CrossRef]

17. Bansal, S.; Kushwaha, J.P.; Sangal, V.K. Electrochemical Treatment of Reactive Black 5 Textile Wastewater: Optimization, Kinetics, and Disposal Study. Water Environ. Res 2013, 85, 2294-2306. [CrossRef]

18. Sirés, I.; Brillas, E. Remediation of water pollution caused by pharmaceutical residues based on electrochemical separation and degradation technologies: A review. Environ. Int. 2012, 40, 212-229. [CrossRef]

19. Liu, Y.-J.; Lo, S.-L.; Liou, Y.-H.; Hu, C.-Y. Removal of nonsteroidal anti-inflammatory drugs (NSAIDs) by electrocoagulation-flotation with a cationic surfactant. Sep. Purif. Technol. 2015, 152, 148-154. [CrossRef]

20. Liu, Y.-J.; Hu, C.-Y.; Lo, S.-L. Direct and indirect electrochemical oxidation of amine-containing pharmaceuticals using graphite electrodes. J. Hazard. Mater. 2019, 366, 592-605. [CrossRef]

21. Mollah, M.Y.A.; Schennach, R.; Parga, J.R.; Cocke, D.L. Electrocoagulation (EC)—Science and applications. J. Hazard. Mater. 2001, 84, 29-41. [CrossRef]

22. Awual, M.R.; Hasan, M.M. A ligand based innovative composite material for selective lead(II) capturing from wastewater. J. Mol. Liq. 2019, 294, 111679. [CrossRef]

23. Awual, M.R.; Hasan, M.M.; Rahman, M.M.; Asiri, A.M. Novel composite material for selective copper(II) detection and removal from aqueous media. J. Mol. Liq. 2019, 283, 772-780. [CrossRef]

24. Awual, M.R. A novel facial composite adsorbent for enhanced copper(II) detection and removal from wastewater. Chem. Eng. J. 2015, 266, 368-375. [CrossRef]

25. Anglada, Á.; Urtiaga, A.; Ortiz, I. Contributions of electrochemical oxidation to waste-water treatment: Fundamentals and review of applications. J. Chem. Technol. Biot. 2009, 84, 1747-1755. [CrossRef]

26. Liu, H.; Zhao, X.; Qu, J. Electrocoagulation in Water Treatment. In Electrochemistry for the Environment; Comninellis, C., Chen, G., Eds.; Springer: New York, NY, USA, 2010; pp. 245-262. [CrossRef]

27. Rychen, P.; Provent, C.; Pupunat, L.; Hermant, N. Domestic and Industrial Water Disinfection Using Boron-Doped Diamond Electrodes. In Electrochemistry for the Environment; Comninellis, C., Chen, G., Eds.; Springer: New York, NY, USA, 2010; pp. 143-161. [CrossRef]

28. Pulkka, S.; Martikainen, M.; Bhatnagar, A.; Sillanpää, M. Electrochemical methods for the removal of anionic contaminants from water-A review. Sep. Purif. Technol. 2014, 132, 252-271. [CrossRef]

29. Griesbach, U.; Malkowsky, I.M.; Waldvogel, S.R. Green Electroorganic Synthesis Using BDD Electrodes. In Electrochemistry for the Environment; Comninellis, C., Chen, G., Eds.; Springer: New York, NY, USA, 2010; pp. 125-141. [CrossRef]

30. Steckhan, E.; Arns, T.; Heineman, W.R.; Hilt, G.; Hoormann, D.; Jörissen, J.; Kröner, L.; Lewall, B.; Pütter, H. Environmental protection and economization of resources by electroorganic and electroenzymatic syntheses. Chemosphere 2001, 43, 63-73. [CrossRef]

31. Dos Santos, A.J.; Cabot, P.L.; Brillas, E.; Sirés, I. A comprehensive study on the electrochemical advanced oxidation of antihypertensive captopril in different cells and aqueous matrices. Appl. Catal. B Environ. 2020, 277, 119240. [CrossRef]

32. Chen, X.; Chen, G.; Yue, P.L. Investigation on the electrolysis voltage of electrocoagulation. Chem. Eng. Sci. 2002, 57, 2449-2455. [CrossRef] 
33. He, C.-C.; Hu, C.-Y.; Lo, S.-L. Integrating chloride addition and ultrasonic processing with electrocoagulation to remove passivation layers and enhance phosphate removal. Sep. Purif. Technol. 2018, 201, 148-155. [CrossRef]

34. Teixeira, S.; Delerue-Matos, C.; Alves, A.; Santos, L. Fast screening procedure for antibiotics in wastewaters by direct HPLC-DAD analysis. J. Sep. Sci. 2008, 31, 2924-2931. [CrossRef] [PubMed]

35. Chou, W.-L.; Wang, C.-T.; Huang, K.-Y.; Liu, T.-C. Electrochemical removal of salicylic acid from aqueous solutions using aluminum electrodes. Desalination 2011, 271, 55-61. [CrossRef]

36. Zhang, G.H.; Yin, L.L.; Zhang, S.T.; Li, X. Adsorption Behavior of Sulfamethoxazole as Inhibitor for Mild Steel in 3\% HCl Solution. Adv. Mater. Res. 2011, 194-196, 8-15. [CrossRef]

37. Ren, M.; Song, Y.; Xiao, S.; Zeng, P.; Peng, J. Treatment of berberine hydrochloride wastewater by using pulse electro-coagulation process with Fe electrode. Chem. Eng. J. 2011, 169, 84-90. [CrossRef]

38. Indermuhle, C.; Martín de Vidales, M.J.; Sáez, C.; Robles, J.; Cañizares, P.; García-Reyes, J.F.; Molina-Díaz, A.; Comninellis, C.; Rodrigo, M.A. Degradation of caffeine by conductive diamond electrochemical oxidation. Chemosphere 2013, 93, 1720-1725. [CrossRef]

39. Gao, S.; Zhao, Z.; Xu, Y.; Tian, J.; Qi, H.; Lin, W.; Cui, F. Oxidation of sulfamethoxazole (SMX) by chlorine, ozone and permanganate-A comparative study. J. Hazard. Mater. 2014, 274, 258-269. [CrossRef]

40. Martins, A.F.; Mallmann, C.A.; Arsand, D.R.; Mayer, F.M.; Brenner, C.G.B. Occurrence of the Antimicrobials Sulfamethoxazole and Trimethoprim in Hospital Effluent and Study of Their Degradation Products after Electrocoagulation. CLEAN Soil Air Water 2011, 39, 21-27. [CrossRef]

(C) 2020 by the authors. Licensee MDPI, Basel, Switzerland. This article is an open access article distributed under the terms and conditions of the Creative Commons Attribution (CC BY) license (http://creativecommons.org/licenses/by/4.0/). 